
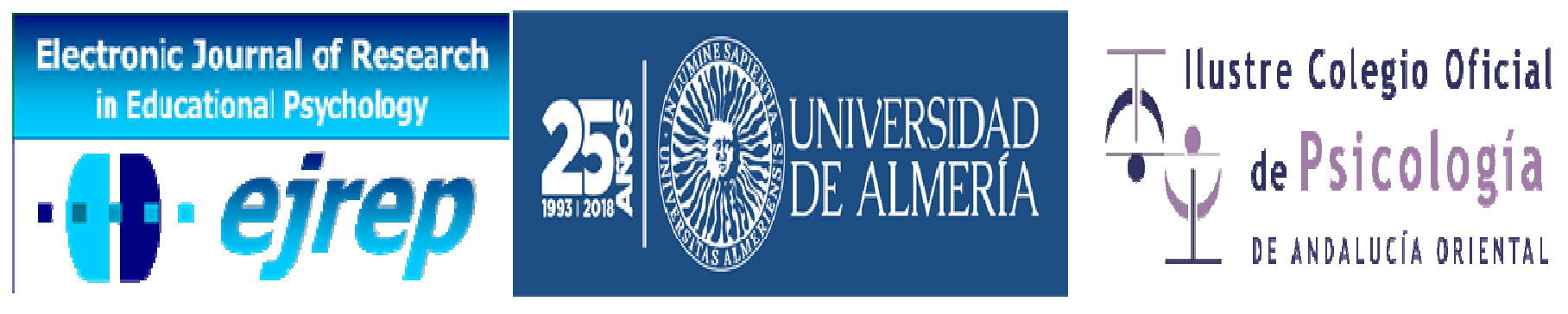

\title{
The Impact of Coping and Help-Seeking on University Students' Academic Achievements
}

\author{
Lawrence Mundia ${ }^{1}$, Masitah Shahrill ${ }^{1}$ \\ ${ }^{1}$ Sultan Hassanal Bolkiah Institute of Education, Universiti Brunei Darussalam, \\ Bandar Seri Begawan
}

\section{Brunei Darussalam}

Correspondence: Masitah Shahrill. Sultan Hassanal Bolkiah Institute of Education, Universiti Brunei Darussalam, Tungku Link Road, Gadong, BE 1410. Brunei Darussalam. E-mail: masitah.shahrill@ubd.edu.bn

(C) University of Almería and Ilustre Colegio Oficial de la Psicología de Andalucía Oriental (Spain) 


\begin{abstract}
Introduction. When faced with challenges or complications, we typically turn to coping. Coping is a multifaceted and multidimensional construct, with many coping mechanisms developed in the form of questionnaires to measure a number of coping styles. Consequently, when we are not able to resolve a problem, we normally seek help from another person. The goal of this current study is to investigate students' coping strategies and help-seeking behaviors while pursuing their studies at a university in Brunei.
\end{abstract}

Method. A questionnaire consisting of questions related to demographic, coping and helpseeking behaviors were disseminated to 395 university students. The final sample analyzed consisted of 352 students (270 females and 82 males). The analyses of the quantitative data involved procedures such as descriptive statistics, inferential statistics and nonparametric statistics.

Results. A two-Way ANOVA and multiple regression analysis identified task-oriented coping and gender as the main effects are significantly related to academic achievement. Both variables had high effect sizes and statistical power. Hierarchical stepwise multiple regression analysis confirmed task-focused coping and female gender as the variables most significantly related to academic success. Binary logistic regression analysis further showed that task-andemotion based coping was significantly related to achieving at or above the $75^{\text {th }}$ percentile. Task-oriented students had higher odds for performing above the third quartile ( $\mathrm{OR}=1.043$, $95 \%$ CI for OR $=1.019-1.069)$. Self-dependent students were 1.9 times more likely to achieve higher than other peers $(\mathrm{OR}=1.930,95 \% \mathrm{CI}=0.791-4.708)$. Students who sought help from lecturers were more likely to perform better than others $(\mathrm{OR}=1.163,95 \% \mathrm{CI}=$ 0.530 - 2.552). Similarly, students who consulted peers had high likelihood for good achievement $(\mathrm{OR}=1.049,95 \% \mathrm{CI}=0.484-2.272)$.

Discussion and Conclusion. The task-oriented coping style was the best achievement predictor for all students with high support needs. The help-seeking resources consulted most by distressed students were self, lecturers, and peers. Students who utilized these three sources of help had high likelihood to obtain good academic results. Moreover, male students need more assistance than the females.

Keywords: Emotion, avoidance, distraction, social diversion, help-seeking sources. 


\section{Resumen}

Introducción. Cuando nos enfrentamos con problemas o complicaciones, solemos recurrir a sobrellevar la situación. El afrontamiento es un constructo multidimensional y multifacético, referidos a los mecanismos de supervivencia desarrollados en forma de cuestionarios para medir una serie de estilos de afrontamiento. En consecuencia, cuando no somos capaces de resolver un problema, solemos buscar la ayuda de otra persona. El objetivo de este estudio fue investigar los estudiantes las estrategias y comportamientos de búsqueda de ayuda mientras proseguían sus estudios en la Universidad.

Método. Un cuestionario de preguntas relativas a la demografía, afrontamiento y comportamientos de búsqueda de ayuda fueron difundidos a 395 estudiantes universitarios. Al final de la muestra analizada se componía de 352 estudiantes (270 mujeres y 82 hombres). Los análisis de los datos cuantitativos involucrados a procedimientos de estadística descriptiva, inferencial y no paramétrica.

Resultados. Un ANOVA de dos vías y el análisis de regresión múltiple identificó afrontamiento orientado a la tarea y el género como los efectos principales se relacionan significativamente con el logro académico. Ambas variables tuvieron tamaños del efecto altos y potencia estadística. El análisis de regresión múltiple stepwise jerárquica confirmado de adaptación centradas en las tareas y el sexo femenino como las variables más significativamente relacionadas con el éxito académico. El análisis de regresión logística binaria demostró, además, que la tarea de la emoción y afrontamiento basado estaba significativamente relacionada con el logro en o por encima del percentil 75. Task-oriented estudiantes tenían mayores probabilidades de realizar por encima del tercer cuartil (OR=1.043, 95\% $\mathrm{CI}=1.019-1.069 \mathrm{U})$. Auto-alumnos dependientes fueron 1,9 veces más probabilidades de lograr mayor que otros pares $(\mathrm{OR}=1.930,95 \% \mathrm{CI}=0.791$ - 4.708). Los estudiantes que buscaron la ayuda de los profesores eran más propensos a realizar mejores que otros $(\mathrm{OR}=1.163,95 \% \mathrm{CI}=0.530-2.552)$. Del mismo modo, los estudiantes que consultaron compañeros tienen altas probabilidades de éxito $(\mathrm{OR}=1.049,95 \% \mathrm{CI}=0,484-2.272)$.

Discusión y Conclusión. Los estilos de afrontamiento orientados a tareas logro fue el mejor predictor que deberían adoptarse para todos los estudiantes con altas necesidades de soporte. Y la ayuda a la búsqueda de recursos consultado más agobiados por los estudiantes fueron auto, profesores y compañeros. Los estudiantes que utilicen estas tres fuentes de ayuda había altas probabilidades de obtener buenos resultados académicos. Además, los alumnos necesitan más ayuda que las alumnas.

Palabras Clave: emoción, evasión, distracción, la desviación social, buscar ayuda. 


\section{Introduction}

In the tertiary education sector, Brunei has a number of state institutions including four universities, one polytechnic and two colleges. There are also privately run colleges. The higher education sector is rapidly expanding with the increase in the number of school leavers. Despite this growing trend, not much research has been done on post-secondary level educational institutions in Brunei. In particular, psychological research on university students' coping strategies and help-seeking behaviors is lacking. This present study was conducted at one of the universities in Brunei (henceforth referred to as the University), and the study attempted to identify ways for assisting students with high support needs.

\section{Research on coping}

According to Lazarus and Folkman (1984), coping is the "constantly changing cognitive and behavioral efforts to manage specific external and / or internal demands that are appraised as taxing or exceeding the resources of the person" (p. 141). When faced with challenges or complications, we typically turn to coping. For example, coping with excruciating pain, academic failure, bereavement, divorce, chronic illness (e.g. HIV/AIDS or cancer), traumatic events (e.g. accident or war), rejection, discrimination, racism, violence, bullying, crime, labelling, stigma, peer pressure, unemployment, poverty, and disability.

Reijntjes, Stegge, and Terwogt (2006) stated that coping is a multifaceted and multidimensional construct, and so far, more than 100 coping mechanisms has been identified in previous research studies (Reevy, 2011). Among the psychometric scales developed in measuring the coping strategies were, in children (by Ayers, Sandler, West, \& Roosa, 1996), in adolescents (by Frydenberg \& Lewis, 1993), and in adults (for example, by Carver, Scheier, \& Weintraub, 1989; Endler \& Parker, 1990; Lazarus \& Folkman, 1988). The inventories created by Ayers et al. (1996) were situational or projective and those by Endler and Parker (1990), Frydenberg and Lewis (1993) and Greenglass, Schwarzer, Jakubiec, Fiksenbaum, and Taubert (1999) were written self-reports. Each of these questionnaires measures a number of coping styles. And these coping methods provide ample explanations and predictions of achievements or failures relating to academic matters (for example, Caprara, Vecchione, Alessandri, Gerbino, \& Barbaranelli, 2010; MacCann, Fogarty, Zeidner, \& Roberts, 2011; Mann, Nota, Soresi, Ferrari, \& Frydenberg, 2011; Noftle \& Robins, 2007). Included in these 
modes are positive or proactive coping (behavioral, emotional, and cognitive engagement), and negative coping (behavioral and cognitive disengagement, behavioral avoidance, and catastrophizing) (Appleton, Christenson, \& Furlong, 2008; Reijntjes et al. 2006; van Uden, Ritzen, \& Pieters, 2013; 2014). The issue of emotional coping is also widely used by many people (see BarOn, 1997; BarOn \& Parker, 2000).

\section{Help-seeking behaviors in non-school contexts}

Previous findings have shown that when a person is not able to resolve his or her own problems, then he or she will normally seek help from another person. However, this may not typically be the case. The findings reported by Komiya, Good, and Sherrod (2000) and Lindinger-Sternart (2014) indicated that men do not typically turn to mental health professionals, when compared to women. When men are confronted with psychological problems, they demonstrated less positive attitudes in turning for help so that they can avoid discussing about stressful events and painful feelings, and this was mainly due to masculine norms and stigma (Lindinger-Sternart, 2014). Additionally those who are active in sports or having an army or police profession in which they possess higher level of masculinity and toughness norms may not usually recognize the professional seeking help benefits such as psychotherapy or even counseling (Steinfeldt \& Steinfeldt, 2012). Besides gender differences in helpseeking behaviors, there may also be cultural differences as well as differences due to educational level. These help-seeking strategies seem to be also used by students in school environments.

\section{The study}

In this study, we aim to identify the participants' coping styles and sources of help, and how these contributed to academic achievement. In addition, the main purpose are listed below:

1) Determine the main and interaction (coping and help-seeking) variables that were significantly associated with academic achievement when other factors were controlled or held constant.

2) Determine the variables, with respect to coping and help-seeking identified to be relatable to the academic achievements when each unneeded term was dropped out step by step.

3) Determine the variables, with respect to coping and help-seeking that predicted academic achievement at a higher level (third quartile and above). 


\section{Method}

\section{Participants}

We distributed the instrument to 395 students, which were selected by the simple random sampling procedure across the university. The final sample collected was reduced to 352 due to a variety of practical problems such as: non-response bias; unusable returns; and missing values. Details of the sample are given in Table 1. The size of the overall sample $(\mathrm{N})$ and subsamples (n) reported vary because of either due to pair-wise or list-wise deletion of cases with missing values. The chi-square and phi coefficient show no significant difference in the composition of the sample by gender and faculty (Table 1).

Table 1. Participants' gender, age, and program by faculty

\begin{tabular}{|c|c|c|c|c|c|c|}
\hline \multirow{2}{*}{ Gender } & \multicolumn{5}{|c|}{ Faculty } & \multirow{2}{*}{ Chi-square (Phi) } \\
\hline & A & $\mathrm{B}$ & $\mathrm{C}$ & $\mathrm{D}$ & Total & \\
\hline Males & 31 & 14 & 30 & 7 & 82 & $\mathrm{X}^{2}(3)=5.056, \mathrm{p}=0.168$ (two-tailed) \\
\hline Females & 126 & 24 & 99 & 21 & 270 & $(\omega=0.120, p=0.168)$ \\
\hline Total & 157 & 38 & 129 & 28 & 352 & \\
\hline \multirow{2}{*}{ Age-groups } & & & Facu & & & \multirow{2}{*}{ Chi-square (Phi) } \\
\hline & A & $\mathrm{B}$ & $\mathrm{C}$ & $\mathrm{D}$ & Total & \\
\hline $18-24$ & 58 & 37 & 122 & 25 & 242 & \multirow{5}{*}{$\begin{array}{l}\text { Not computed due to presence of } \\
\text { empty cells and cells with small fre- } \\
\text { quencies less than } 5\end{array}$} \\
\hline $25-30$ & 58 & 1 & 4 & 3 & 66 & \\
\hline $31-36$ & 28 & 0 & 0 & 0 & 28 & \\
\hline $37-42$ & 11 & 0 & 1 & 0 & 12 & \\
\hline Total & 155 & 38 & 127 & 28 & 348 & \\
\hline \multirow{2}{*}{ Program } & & & Facu & & & \multirow{2}{*}{ Chi-square (Phi) } \\
\hline & A & $\mathrm{B}$ & $\mathrm{C}$ & $\mathrm{D}$ & Total & \\
\hline Undergraduate & 0 & 36 & 128 & 25 & 189 & \multirow{3}{*}{$\begin{array}{l}\text { Not computed due to presence of } \\
\text { empty cells and cells with small fre- } \\
\text { quencies less than } 5\end{array}$} \\
\hline Graduate & 155 & 1 & 1 & 3 & 160 & \\
\hline Total & 155 & 37 & 129 & 28 & 349 & \\
\hline
\end{tabular}

Notes: Faculty A is a graduate faculty specialising in education programs, Faculty B caters to the sciences programs, Faculty $\mathrm{C}$ focuses on the arts and humanities programs, and Faculty $\mathrm{D}$ focuses on the business and economics programs. 


\section{Instruments}

The data were collected with an instrument labeled as Parts A, B and C. Part A - the instructions to participants, collected registration numbers and informed consent. With consent of the participants, we also obtained from the University Examinations Office the students' achievement data in form of cumulative GPA scores (cGPA) using their confidential registration numbers collected in this part. The cGPAs were standardized weighted mean scores computed by the same formula across all the faculties of the university and could therefore be used to compare students' performance directly. The cGPA scores in the present study were used as the dependent variable. Earlier studies, such as by Noftle and Robins (2007) and Reevy (2011), also made use of GPA as a measure of students' academic achievement.

Part B consisted of the researcher-constructed 5-item demographic survey that collected biographical data such as gender, age, study program, faculty in which the student was enrolled, and the main source of help that the student used or consulted when faced with challenging academic and personal problems. The data collated from gender, age, program, faculty, help-sources, and achievement were used as grouping independent variables when calculating the various statistical analyses.

Part $\mathrm{C}$ had the Coping Inventory for Stressful Situations for adults (hereafter referred to as CISS, Endler \& Parker, 1990). The CISS scale in Part C was a written self-report that measures coping with 48 items in total. There were 16 items in each category assessing the task-oriented coping, emotion-oriented coping and avoidance-oriented coping. For our study in particular, we have divided the avoidance scale into two subscales: 10 items under distraction and 6 items for social diversion. There are three filler items in the avoidance subscale that are not usually used but we utilized them also in the present study. The five CISS scales were Likert-type format with a 5-point response ranging from $1=$ not at all, to $5=$ very much. Presented in Table 2 are the descriptive statistics and reliability indices of the scales. The results indicated that all the CISS scales had satisfactory and acceptable levels of alpha reliability. In addition, the high item-to-scale correlations provided evidence about the unidimensionality of items in each CISS subscale. According to Rust and Golombok (1989), based on psychometric theory, an item is suitable if the item positively and highly correlates with the total scores of which it does not form a part. 
Table 2. Subscale descriptive statistics and reliability

\begin{tabular}{lcccccc}
\hline Scale & Items & Mean & SEm & SD & $\begin{array}{c}\text { Range of Item-to- } \\
\text { Scale Correlations } \\
\text { (Mean) }\end{array}$ & $\begin{array}{c}\text { Alpha } \\
\text { reliability }\end{array}$ \\
\hline Task & 16 & 59.538 & 0.423 & 7.916 & $\begin{array}{c}0.390-0.610 \\
(0.499)\end{array}$ & 0.866 \\
Emotion & 16 & 49.102 & 0.519 & 9.572 & $\begin{array}{c}0.290-0.580 \\
(0.453)\end{array}$ & 0.841 \\
Avoidance & 16 & 51.599 & 0.791 & 9.547 & $\begin{array}{c}0.290-0.550 \\
(0.415)\end{array}$ & 0.813 \\
Distraction & 10 & 33.463 & 0.310 & 6.697 & $\begin{array}{c}0.260-0.560 \\
(0.417)\end{array}$ & 0.755 \\
Social & 6 & 18.118 & 0.201 & 4.083 & $\begin{array}{c}0.230-0.610 \\
(0.411)\end{array}$ & 0.678 \\
Diversion & & & & & & \\
\hline
\end{tabular}

The criterion-related validity of the CISS scales was also assessed. The inter-scale correlations in Table 3 formed two clusters and may be interpreted in two different ways. Cluster 1 consisted of low correlations obtained between Task, Emotion and Avoidance subscales. The low correlations in this cluster suggested that the scales were correlates measures of conceptually and empirically different attributes and did not replicate each other. For these scales, the low correlations confirm that the questionnaires were distinct from each other and reflected relatively high levels of independence in functioning between them thereby providing good quantitative evidence for the scales' discriminant or divergent validity.

On the other hand, Cluster 2 comprised of correlations obtained between Avoidance, Distraction and Social Diversion subscales. The moderate-to-high significant correlations in this cluster implied that the scales (to some extent) overlapped and measured the same construct. Previous research also found these three subscales to be highly inter-correlated (e.g. Bouteyre et al., 2007). All the items for both the Distraction and Social Diversion scales were derived from the Avoidance scale. However, because two of the correlations are moderate (except one), the amount of duplication (redundancy or common variance, $r^{2}$ ) was little and negligible, except for the correlation between Avoidance and Distraction. The paired scales in Cluster 2 could therefore be said to have satisfactory divergent and convergent validity.

Besides, the divergent and convergent validity, we further assessed the construct validity of the CISS scale in the tertiary students' context of Brunei using the Exploratory Factor 
Analysis (EFA). Overall, the EFA produced three main principal component factors rotated by the varimax method with Kaiser normalization (eigenvalue greater than 1). All the rotated factors had positive loadings of 0.300 and above. Factor 1 (Task-oriented coping) had an eigenvalue of 5.774 and accounted for $12.028 \%$ of the variance in coping as measured by the CISS in the present study. Of the 16 items comprising this subscale, 13 were correctly assigned to Factor 1 by the EFA. Factor 2 (Emotion-focused coping, eigenvalue $=5.070$ ) accounted for $10.562 \%$ of the variance in coping. Eleven (11) items in this scale out of 16 were specifically assigned to Factor 2 by EFA. Factor 3 (Avoidance-related coping (eigenvalue = $4.543 ; 9.465 \%$ variance accounted) had only 9 items appropriately assigned to it by EFA. The other seven (7) of the 16 items in this scale belonged to the distraction and social diversion subscales. Altogether, the three major factors of the CISS scale accounted for $32.055 \%$ of the variance in coping for the current study. Moreover, all the questionnaire scores used in the present study were considered to have good ecological validity in that all the data were collected in the participants' usual university lecture environments so that the respondents were not anxious, cautious and defensive when completing the research instruments.

Table 3. Discriminant and convergent validity of the scales

\begin{tabular}{lllll}
\hline Scale & Task & Emotion & Avoidance & Distraction \\
\hline Task & 1 & & & \\
Emotion & -.032 & 1 & & \\
Avoidance & $.124^{*}$ & $.413^{* *}$ & 1 & 1 \\
Distraction & .059 & $.423^{* *}$ & $.952^{* *}$ & $.434^{* *}$ \\
Social Diversion & $.228^{* *}$ & $.226^{* *}$ & $.665^{* *}$ & \\
${ }^{*} p<.05 ; * * p<.01$ (both two-tailed) & & &
\end{tabular}

\section{Procedures}

Brunei currently has four universities. The names of the University and Faculties on which this study was based were concealed in line with the anonymity ethical rules. Prior to collecting the data, the participants were verbally informed about the purpose and objectives of the study according to their university's research ethics requirements. In addition, participants were also verbally informed of the ethical conditions and legal rights for involving them in the study. Participants were assured that both the registration numbers collected in the biodata section of the instrument and their cGPA scores obtained from the University Examinations Office would strictly be: kept confidential; used for research purposes only; and only the 
researchers would be granted access to the students' cGPA by the Examinations Office. In addition, we promised students that any information collected from them using the research instruments would only be analyzed and reported at a group level. We did not use any deception in the study. Questionnaires were distributed only to those students who felt comfortable with the study and voluntarily agreed to participate. Furthermore, the instrument did not need to be translated into Bahasa Melayu (or the Malay language), the most widely spoken language in Brunei, as it was written in simple English for people with a minimum of Grade 10 education.

\section{Data analysis}

A field survey approach was used for this study rather than the online, postal, and telephone survey strategies. In this way, we involved many students and gave them on-the-spot assistance when required. The five subscales (Task, Emotion, Avoidance, Distraction, and Social Diversion) were scored according to instructions in the CISS technical manual (Endler \& Parker, 1990). Specifically, only raw data were used in this study. The raw quantitative data from the demographic section and each CISS subscale were analyzed by a variety of procedures: descriptive statistics (frequencies, percentages, mean, and standard deviation); inferential statistics (Pearson correlations, exploratory factor analysis, univariate Two-Way ANOVA, hierarchical regression analysis, and binary logistic regression analysis); and nonparametric statistics (chi-square including the phi coefficient).

\section{Results}

We initially explored the relationship between coping and help-seeking using univariate Two-Way ANOVA (see Table 4). The analysis showed that only two main effects (taskoriented coping and gender) were significantly related to the academic achievement. Both variables had higher effect sizes (partial eta squared) and observed statistical power and became candidates for further analysis. The only lower-order interaction term (gender X help source) provided by SPSS in this table was not statistically significant. 
Table 4. Univariate Two-Way ANOVA tests of between-subjects effects on cGPA

\begin{tabular}{|c|c|c|c|c|c|c|c|c|}
\hline Source & & $\begin{array}{l}\text { Type III } \\
\text { Sum of } \\
\text { Squares }\end{array}$ & $\mathrm{df}$ & $\begin{array}{l}\text { Mean } \\
\text { Square }\end{array}$ & $\mathrm{F}$ & Sig. & $\begin{array}{c}\text { Partial } \\
\text { Eta Squa- } \\
\text { red }\end{array}$ & $\begin{array}{c}\text { Observed } \\
\text { Power }\end{array}$ \\
\hline \multirow[t]{2}{*}{ Task } & Hypothesis & 13.537 & 1 & 13.537 & 45.240 & $0.000 * *$ & 0.132 & 1.000 \\
\hline & Error & 89.171 & 298 & 0.299 & & & & \\
\hline \multirow[t]{2}{*}{ Emotion } & Hypothesis & 0.207 & 1 & 0.207 & 0.693 & 0.406 & 0.002 & 0.132 \\
\hline & Error & 89.171 & 298 & 0.299 & & & & \\
\hline \multirow[t]{2}{*}{ Avoidance } & Hypothesis & 1.064 & 1 & 1.064 & 3.554 & 0.060 & 0.012 & 0.468 \\
\hline & Error & 89.171 & 298 & 0.299 & & & & \\
\hline \multirow[t]{2}{*}{ Distraction } & Hypothesis & 0.849 & 1 & 0.849 & 2.838 & 0.093 & 0.009 & 0.390 \\
\hline & Error & 89.171 & 298 & 0.299 & & & & \\
\hline Social & Hypothesis & 0.594 & 1 & 0.594 & 1.986 & 0.160 & 0.007 & 0.290 \\
\hline Diversion & Error & 89.171 & 298 & 0.299 & & & & \\
\hline \multirow[t]{2}{*}{ Gender } & Hypothesis & 2.313 & 1 & 2.313 & 12.943 & $0.005 * *$ & 0.578 & 0.895 \\
\hline & Error & 1.688 & 9.445 & 0.179 & & & & \\
\hline \multirow[t]{2}{*}{ Help Source } & Hypothesis & 1.119 & 7 & 0.160 & 0.819 & 0.586 & 0.275 & 0.241 \\
\hline & Error & 2.944 & 15.074 & 0.195 & & & & \\
\hline Gender $\mathbf{X}$ & Hypothesis & 0.776 & 5 & 0.155 & 0.519 & 0.762 & 0.009 & 0.192 \\
\hline Help Source & Error & 89.171 & 298 & 0.299 & & & & \\
\hline
\end{tabular}

To elaborate further, the univariate multiple regression analysis reported in Table 5 confirmed task-oriented coping and female gender as the best predictors of academic achievement in the current study. Each of these two variables was significantly related to academic achievement when other factors were controlled or held constant. The five first-order interaction terms in Table 6 (female gender versus each of the five separate help-sources) were all insignificantly related to academic achievement, implying they had no joint effects.

Table 5. Univariate multiple regression analysis on cGPA

\begin{tabular}{|c|c|c|c|c|c|c|c|c|}
\hline \multirow[t]{3}{*}{ Variable } & \multirow[t]{3}{*}{ B } & \multirow[t]{3}{*}{$\begin{array}{l}\text { Std. } \\
\text { Error }\end{array}$} & \multirow[t]{3}{*}{$\mathrm{t}$} & \multirow[t]{3}{*}{ Sig. } & \multicolumn{2}{|c|}{$\begin{array}{c}95 \% \text { Confidence } \\
\text { Interval }\end{array}$} & \multirow[t]{3}{*}{$\begin{array}{l}\text { Partial Eta } \\
\text { Squared }\end{array}$} & \multirow[t]{3}{*}{$\begin{array}{c}\text { Observed } \\
\text { Power }\end{array}$} \\
\hline & & & & & Lower & Upper & & \\
\hline & & & & & Bound & Bound & & \\
\hline Task & 0.027 & 0.004 & 6.726 & $0.000 * *$ & 0.019 & 0.035 & 0.132 & 1.000 \\
\hline Emotion & -0.003 & 0.004 & -0.833 & 0.406 & -0.010 & 0.004 & 0.002 & 0.132 \\
\hline Avoidance & -0.032 & 0.017 & -1.885 & 0.060 & -0.066 & 0.001 & 0.012 & 0.468 \\
\hline Distraction & 0.061 & 0.036 & 1.685 & 0.093 & -0.010 & 0.133 & 0.009 & 0.390 \\
\hline $\begin{array}{l}\text { Social Diver- } \\
\text { sion }\end{array}$ & 0.033 & 0.023 & 1.409 & 0.160 & -0.013 & 0.078 & 0.007 & 0.290 \\
\hline
\end{tabular}




$\begin{array}{lllllllll}\text { Female } & 1.901 & 0.306 & 6.222 & 0.000 * * & 1.300 & 2.503 & 0.115 & 1.000 \\ \text { Self } & 0.247 & 0.129 & 1.920 & 0.056 & -0.006 & 0.500 & 0.012 & 0.482 \\ \text { Library } & 0.073 & 0.115 & 0.636 & 0.525 & -0.153 & 0.298 & 0.001 & 0.097 \\ \text { Computer } & -0.135 & 0.115 & -1.173 & 0.242 & -0.362 & 0.092 & 0.005 & 0.216 \\ \text { Lab } & 0.116 & 0.115 & 1.005 & 0.316 & -0.111 & 0.342 & 0.003 & 0.171 \\ \text { Lecturers } & 0.011 & 0.110 & 0.103 & 0.918 & -0.206 & 0.228 & 0.000 & 0.051 \\ \begin{array}{l}\text { Peers } \\ \text { Female X }\end{array} & -0.226 & 0.265 & -0.852 & 0.395 & -0.748 & 0.296 & 0.002 & 0.136 \\ \begin{array}{l}\text { Self } \\ \text { Female X }\end{array} & 0.085 & 0.272 & 0.313 & 0.754 & -0.451 & 0.621 & 0.000 & 0.061 \\ \text { Library } & & & & & & & & \\ \text { Female X } & & & & & & & & \\ \text { Computer } & 0.281 & 0.274 & 1.028 & 0.305 & -0.257 & 0.820 & 0.004 & 0.176 \\ \text { Lab } & & & & & & & & \\ \text { Female X } & -0.074 & 0.217 & -0.341 & 0.733 & -0.500 & 0.352 & 0.000 & 0.063 \\ \text { Lecturers } & & & & & & & & \\ \text { Female X } & 0.040 & 0.222 & 0.178 & 0.858 & -0.397 & 0.477 & 0.000 & 0.054 \\ \begin{array}{l}\text { Peers } \\ * * p<.01 \text { (two-tailed) }\end{array} & & & & & & & & \end{array}$

Using a more robust statistical procedure (hierarchical stepwise multiple regression analysis with backward elimination) we identified the variables that incrementally contributed variance to academic achievement step by step. SPSS program (Version 22) iteratively produced six steps each of which was a model. The output presented in Table 6 shows only Step 1 (first model) and Step 6 (last model) both of which confirmed task-focused coping behavior and gender as the variables that were most significantly related to the academic achievement. These two variables remained as the strongest and best predictors of academic achievement throughout the six steps and made each model to be significant. Because of the constant and uniform effects of the two dominant variables (task-oriented coping and gender), there were no significant differences in $\mathrm{R}, \mathrm{R}^{2}$, $\mathrm{R}$ Square Change, and FChange (FA) statistics in Steps 2-6 (see Table 7). 
Table 6. Hierarchical multiple regression analysis with backward elimination

\begin{tabular}{|c|c|c|c|c|c|c|c|c|}
\hline \multicolumn{2}{|c|}{ Model } & \multicolumn{2}{|c|}{$\begin{array}{r}\text { Unstandardized } \\
\text { Coefficients }\end{array}$} & \multirow{3}{*}{$\begin{array}{r}\begin{array}{r}\text { Standardized } \\
\text { Coefficients }\end{array} \\
\text { Beta }\end{array}$} & \multirow[b]{3}{*}{$\mathrm{t}$} & \multirow[b]{3}{*}{ Sig. } & \multicolumn{2}{|c|}{$95 \% \mathrm{CI}$ for $\mathrm{B}$} \\
\hline & & & Std. & & & & \multirow{2}{*}{$\begin{array}{l}\text { Lower } \\
\text { Bound }\end{array}$} & \multirow{2}{*}{$\begin{array}{l}\text { Upper } \\
\text { Bound }\end{array}$} \\
\hline & & $\mathrm{B}$ & Error & & & & & \\
\hline \multirow[t]{7}{*}{1} & Help Source & 0.011 & 0.018 & 0.021 & 0.611 & 0.541 & -0.024 & 0.045 \\
\hline & Task & 0.041 & 0.003 & 0.756 & 13.656 & $0.000 * *$ & 0.035 & 0.047 \\
\hline & Emotion & 0.001 & 0.004 & 0.019 & 0.363 & 0.717 & -0.006 & 0.008 \\
\hline & Avoidance & -0.024 & 0.018 & -0.586 & -1.388 & 0.166 & -0.059 & 0.010 \\
\hline & Distraction & 0.052 & 0.037 & 0.426 & 1.378 & 0.169 & -0.022 & 0.125 \\
\hline & $\begin{array}{l}\text { Social } \\
\text { Diversion }\end{array}$ & 0.026 & 0.024 & 0.131 & 1.092 & 0.276 & -0.021 & 0.072 \\
\hline & Gender & 0.413 & 0.072 & 0.229 & 5.770 & $0.000 * *$ & 0.272 & 0.554 \\
\hline \multirow[t]{2}{*}{6} & Task & 0.041 & 0.002 & 0.756 & 20.777 & $0.000 * *$ & 0.038 & 0.045 \\
\hline & Gender & 0.424 & 0.066 & 0.235 & 6.463 & $0.000 * *$ & 0.295 & 0.553 \\
\hline
\end{tabular}

Dependent Variable: cGPA scores

Table 7. Variations to $R, R^{2}$ and F Change in hierarchical multiple regression analysis with backward elimination

\begin{tabular}{|c|c|c|c|c|c|c|c|c|c|}
\hline \multirow[b]{2}{*}{ Model } & \multirow[b]{2}{*}{$\mathrm{R}$} & \multirow[b]{2}{*}{$\begin{array}{c}\mathrm{R} \\
\text { Square }\end{array}$} & \multirow[b]{2}{*}{$\begin{array}{l}\text { Adjusted } \\
\text { R Square }\end{array}$} & \multirow{2}{*}{$\begin{array}{l}\text { Std. Error } \\
\text { of the Es- } \\
\text { timate }\end{array}$} & \multicolumn{5}{|c|}{ Change Statistics } \\
\hline & & & & & $\begin{array}{l}\text { R Square } \\
\text { Change }\end{array}$ & $\begin{array}{l}\text { F Chan- } \\
\text { ge }\end{array}$ & df1 & $\mathrm{df} 2$ & $\begin{array}{l}\text { Sig. F } \\
\text { Change }\end{array}$ \\
\hline 1 & $0.985^{\mathrm{a}}$ & 0.970 & 0.970 & 0.573 & 0.970 & 1441.542 & 7 & 310 & 0.000 \\
\hline 2 & $0.985^{\mathrm{c}}$ & 0.970 & 0.970 & 0.572 & 0.000 & 0.132 & 1 & 310 & 0.717 \\
\hline 3 & $0.985^{\mathrm{d}}$ & 0.970 & 0.970 & 0.572 & 0.000 & 0.467 & 1 & 311 & 0.495 \\
\hline 4 & $0.985^{\mathrm{e}}$ & 0.970 & 0.970 & 0.572 & 0.000 & 1.303 & 1 & 312 & 0.255 \\
\hline 5 & $0.985^{\mathrm{f}}$ & 0.970 & 0.970 & 0.572 & 0.000 & 0.663 & 1 & 313 & 0.416 \\
\hline 6 & $0.985^{\mathrm{g}}$ & 0.970 & 0.970 & 0.571 & 0.000 & 0.056 & 1 & 314 & 0.813 \\
\hline
\end{tabular}

Dependent Variable: cGPA scores

Using Quartile $3(\mathrm{cGPA}=3.670)$ as a criterion cutoff point, we dichotomized the participants' cGPA scores to create two categories of the respondents, namely the higher achievers (with cGPA at Quartile 3 and above, coded 1) and the low achievers (cGPA below Quartile 3, coded 0). Applying the hierarchical binary logistic regression analysis with backward elimination, we determined the coping variables and help sources that might significantly support and enable students to perform at Quartile 3 and above (see Table 8). 
Table 8. Hierarchical binary logistic regression analysis with backward elimination

\begin{tabular}{|c|c|c|c|c|c|c|c|c|c|}
\hline & \multirow[b]{2}{*}{ B } & \multirow[b]{2}{*}{ S.E. } & \multirow[b]{2}{*}{ Wald } & \multirow[b]{2}{*}{ df } & \multirow[b]{2}{*}{ Sig. } & \multirow[b]{2}{*}{ OR } & \multicolumn{2}{|c|}{$95 \% \mathrm{CI}$ for OR } \\
\hline & & & & & & & & Lower & Upper \\
\hline \multirow[t]{13}{*}{ Step 1} & Help Source & & & 3.683 & 7 & 0.816 & & & \\
\hline & Self & 0.658 & 0.455 & 2.090 & 1 & 0.148 & 1.930 & 0.791 & 4.708 \\
\hline & Library & -0.277 & 0.440 & 0.397 & 1 & 0.529 & 0.758 & 0.320 & 1.795 \\
\hline & $\begin{array}{l}\text { Computer } \\
\text { Lab }\end{array}$ & -0.196 & 0.437 & 0.201 & 1 & 0.654 & 0.822 & 0.349 & 1.937 \\
\hline & Lecturers & 0.151 & 0.401 & 0.143 & 1 & 0.706 & 1.163 & 0.530 & 2.552 \\
\hline & Peers & 0.048 & 0.394 & 0.015 & 1 & 0.903 & 1.049 & 0.484 & 2.272 \\
\hline & Task & 0.043 & 0.012 & 12.264 & 1 & $0.000 * *$ & 1.043 & 1.019 & 1.069 \\
\hline & Emotion & -0.050 & 0.014 & 12.456 & 1 & $0.000 * *$ & 0.951 & 0.925 & 0.978 \\
\hline & Avoidance & -0.061 & 0.070 & 0.762 & 1 & 0.383 & 0.941 & 0.820 & 1.079 \\
\hline & Distraction & 0.113 & 0.150 & 0.575 & 1 & 0.448 & 1.120 & 0.835 & 1.502 \\
\hline & Social & 0.063 & 0.095 & 0.432 & 1 & 0.511 & 1.065 & 0.883 & 1.283 \\
\hline & Diversion & & & & & & & & \\
\hline & Female & 1.136 & 0.353 & 10.353 & 1 & $0.001 * *$ & 0.321 & 0.161 & 0.641 \\
\hline \multirow[t]{3}{*}{ Step 5} & Task & 0.038 & 0.009 & 17.158 & 1 & $0.000 * *$ & 1.039 & 1.020 & 1.057 \\
\hline & Emotion & -0.058 & 0.011 & 26.794 & 1 & $0.000 * *$ & 0.943 & 0.923 & 0.964 \\
\hline & Female & 1.103 & 0.346 & 10.173 & 1 & $0.001 * *$ & 0.332 & 0.169 & 0.654 \\
\hline
\end{tabular}

Dependent Variable: cGPA scores

$* * p<.01$ (two-tailed)

Of the five CISS coping strategies, only task-and-emotion based techniques were positively and significantly related to achieving at or above Quartile 3 level. However, emotion coping had an inverse relationship with academic achievement in our study. Compared to low achievers (reference group), the more able students who scored high on the task-oriented coping variable had higher odds for achieving at the third quartile and above in Step 1 (OR = $1.043,95 \%$ CI for OR $=1.019-1.069$ ). Due to the negative B coefficients, high performing students who extensively depended on negative emotion coping were less likely to achieve at the third quartile or above in Step $1(\mathrm{OR}=0.951,95 \% \mathrm{CI}=0.925-0.978)$ and Step $5(\mathrm{OR}=$ $0.943 ; 95 \% \mathrm{CI}=0.923$ - 0.964). In both Step 1 and Step 5, task and emotion oriented coping remained strongly related to achievement with high and low odds, respectively.

Similarly, the female gender variable was also significantly related to achievement in both Step1 and Step 5. Thus females did not only have higher odds for performing well than their male counterparts in both the lower and upper achieving groups, but were also most likely to score at the third quartile and above (Step $5 \mathrm{OR}=0.332,95 \% \mathrm{CI}=0.169-0.654$ ). Although not significantly related to academic achievement, three help-source variables (the self, lecturers, and peers) had high tends or patterns for performing well. Compared to those in the low achieving group, high achievers who were self-dependent were 1.9 times more likely to 
perform at the third quartile and above than most other peers (Step $1 \mathrm{OR}=1.930,95 \% \mathrm{CI}=$ $0.791-4.708)$. Higher achievers who sought help from lecturers were more likely to perform much better than others (Step $1 \mathrm{OR}=1.163,95 \% \mathrm{CI}=0.530-2.552$ ). In the same way, students who consulted peers had high likelihood for good achievement (Step 1 OR $=1.049$, $95 \% \mathrm{CI}=0.484-2.272$ ). The model summary and tests of model coefficients for the hierarchical binary logistic regression analysis are presented in Table 9.

Table 9. Model summary and tests of model coefficients ${ }^{a}$

\begin{tabular}{cccccc}
\hline Step & $\begin{array}{c}\text { Cox \& Snell R } \\
\text { Square }\end{array}$ & $\begin{array}{c}\text { Nagelkerke R } \\
\text { Square }\end{array}$ & $\mathrm{X}^{2}$ & $\mathrm{df}$ & Sig \\
\hline 1 & 0.225 & 0.301 & 80.980 & 13 & 0.000 \\
2 & 0.214 & 0.285 & -4.677 & 7 & 0.699 \\
3 & 0.212 & 0.283 & -0.787 & 1 & 0.375 \\
4 & 0.212 & 0.282 & -0.077 & 1 & 0.782 \\
5 & 0.209 & 0.279 & -1.033 & 1 & 0.309 \\
\hline
\end{tabular}

${ }^{\mathrm{a}} \mathrm{A}$ negative Chi-square value indicates that the Chi-square value has decreased from the previous step.

\section{Discussion}

The study examined the participants' coping strategies and help-seeking behaviors while pursuing their studies at the university. We briefly discuss below the major findings.

\section{Task-oriented coping}

The task-oriented coping style was the best achievement predictor for all students particularly those with high support needs. The task-oriented coping is the equivalent of productive coping in the ACS scale (Frydenberg \& Lewis, 1993) and active coping in the COPE Scale (Carver et al., 1989). It is also generally referred to as the behavioral engagement coping (Reijntjes et al., 2006; van Uden et al., 2013; 2014) or as proactive coping (Greenglass et al., 1999). These variables correlate with academic achievement or GPA and with personality traits such as conscientiousness and openness (see Reevy, 2011). If task-oriented coping was to be used appropriately and proficiently, it could assist students to achieve higher academic results. Previous studies suggest that coping strategies are teachable and can be adjusted appropriately (Bar-On \& Parker, 2000; Reevy, 2011; Reijntjes et al., 2006; van Uden et al., $2013,2014)$. Thus, we recommend motivational talks, seminars, and workshops to be conducted to all categories of students in the effective use of task-oriented coping strategy. Indi- 
vidual counseling could be provided to students with high support needs using Cognitive Behavior Therapy (CBT) and appropriate educational interventions. This would be helpful particularly to the weak or low scoring students who are vulnerable and at risk of failing.

\section{Emotion-oriented coping}

Emotion-oriented coping was second in popularity to task-focused coping but correlated negatively with achievement. There is evidence from research suggesting that emotional engagement in learning enables students to enhance their intrinsic interest and internal motivation to learning (van Uden et al. 2013, 2014). Furthermore, BarOn (1997) and Bar-On and Parker (2000) found that high scorers on the Emotional Intelligence or the EI tests (especially the intrapersonal subscale) were emotionally stable people, able to tolerate stress and were also relaxed, composed and optimistic. Additionally, people with positive emotions also tend to internalize causes of their success or their failure to personal attributes. BarOn and Parker (2000) described a number of strategies that could be used by counselors and psychologists to help students increase their EI and thereby withstand distress more effectively. Moreover, MacCann et al. (2011) observed that coping mediated the connection between academic achievement and EI.

\section{Avoidance, distraction and social diversion coping}

These are three forms of non-productive or dysfunctional coping that counseling and psychotherapy should dissuade students from practicing them. Workshops, seminars and information campaigns should be mounted to sensitize students about the dangers of these undesirable coping strategies. Studies by Pabiton $(2004,2007)$ and Chan and Lim (2006) indicated that university students generally enjoy using the social diversion component within the avoidance-oriented coping. From these findings, it can be suggested that the use of cognitive behavioral therapies in reducing dependence on non-productive coping might be beneficial in assisting the participants to cope effectively with stress. This is because all the five CISS coping strategies investigated in the present study required cognition and adaptive behavior. 


\section{Participants' help-seeking behaviors}

The resources consulted most by distressed students were self, lecturers, and peers. Though not significantly related to academic achievement, each of these variables had potential to impact achievement positively. Students who utilized these three sources of help had high likelihood to obtain good academic results in the current study. Previous studies showed that students in other countries also used these three sources of help (see Chan \& Lim, 2006). The most important psychological factor that participants in present study used and which should be encouraged in all students was the self or self-efficacy (SE). The SE trait is essential and needs to be fostered to our students, as it will empower them to be responsible in owning and solving their difficulties. In addition, according to van Uden et al., (2013, 2014), SE is correlated with behavioral engagement, emotional engagement, and cognitive engagement. Mann et al. (2011) stated that higher SE scores related positively and significantly with productive coping scores while low SE scores correlated with procrastination and nonproductive coping strategies. Importantly, SE correlates to academic achievement (Caprara et al., 2010). Attention and priority in future studies should focus at exploring the many ways SE and other self-related attributes could be built up in tertiary students. The academic skills of female students need to be identified and imparted to males as well.

\section{Conclusion}

The survey investigated the extent to which coping and help-seeking impact achievement positively. Task-focused coping and help from self, peers and lecturers were found to be effective. Moreover, male students need more assistance than the females. By using mixedmethods research in the future, it is anticipated that further insights can be provided on the means in which participants apply the various coping strategies and the reliable help-seeking resources; and also the types of educational and counseling interventions most benefitting to students with high support needs due to using dysfunctional and ineffective coping strategies and sources of help.

This present study had several limitations with the major limitation being the lack of qualitative data component to enhance the findings from the quantitative data collected. Nevertheless, the results of the study do have practical significance despite this limitation. 


\section{References}

Appleton, J. J., Christenson, S. L., \& Furlong, M. J. (2008). Student engagement with school: Critical conceptual and methodological issues of the construct. Psychology in the Schools, 45(5), 369-386. https://doi.org/10.1002/pits.20303

Ayers, T. S., Sandler, I. N., West, S. G., \& Roosa, M. W. (1996). A dispositional and situational assessment of children's coping: Testing alternative models of coping. Journal of Personality, 64(4), 923-958. https://doi.org/10.1111/j.1467-6494.1996.tb00949.x

Bar-On, R. (1997). BarOn Emotional Quotient Inventory: Technical Manual. North Toronto, ON: Multi-Health Systems.

Bar-On, R., \& Parker, J. D. A. (2000). BarOn Emotional Quotient Inventory: Youth Version: Technical Manual. North Tonawanda, NY: Multi-Health Systems.

Bouteyre, E., Maurel, M., \& Bernand, J-L. (2007). Daily hassles and depressive symptoms among first year psychology students in France: The role of coping and social support. Stress and Health, 23(2), 93-99. https://doi.org/10.1002/smi.1125

Chan, W. M., \& Lim, K. M. (2006). Adolescent foreign students' preferred sources of help for academic and interpersonal problems. Journal of Applied Research in Education, 10, 87-95.

Caprara, G. V., Vecchione, M., Alessandri, G., Gerbino, M., \& Barbaranelli, C. (2010). The contribution of personality traits and self-efficacy beliefs to academic achievement: A longitudinal study. British Journal of Educational Psychology, 81(1), 78-96. https://doi.org/10.1348/2044-8279.002004

Carver, C. S., Scheier, M. F., \& Weintraub, J. K. (1989). Assessing coping strategies: A theoretically-based approach. Journal of Personality and Social Psychology, 56(2), 267283. https://doi.org/10.1037/0022-3514.56.2.267

Endler, N. S., \& Parker, J. D. A. (1990). Coping Inventory for Stressful Situations (CISS). North Tonawanda, NY: Multi-Health Systems.

Frydenberg, E., Lewis, R. (1993). Adolescent coping scale. Administrators manual. Hawthorn, Victoria: Australian Council for Educational Research. https://doi.org/10.1006/jado.1993.1024

Greenglass, E. R., Schwarzer, R., Jakubiec, D., Fiksenbaum, L., \& Taubert, S. (1999). The proactive coping inventory, PCI): A multidimensional research instrument. Retrieved August 3, 2014, from http://www.userpage.fu-berlin.de/ health/greenpci.htm

Lazarus, R. S., \& Folkman, S. (1984). Stress, appraisal and coping. New York, NY: Springer. 
Lazarus, R. S., \& Folkman, S. (1988). The ways of coping questionnaire, WCQ. Palo Alto, CA: Consulting Psychologists Press.

Lindinger-Sternart, S. (2014). Help-seeking behaviors of men for mental health and the impact of diverse cultural backgrounds. International Journal of Social Science Studies, 3(1), 1-6. https://doi.org/10.11114/ijsss.v3i1.519

Komiya, N., Good, G. E., \& Sherrod, N. B. (2000). Emotional openness as a predictor of college students' attitudes toward seeking psychological help. Journal of Counseling Psychology, 47(1), 138-143. https://doi.org/10.1037/0022-0167.47.1.138

MacCann, C., Fogarty, G. J., Zeidner, M., \& Roberts, R. D. (2011). Coping mediates the relationship between emotional intelligence (EI) and academic achievement. Contempo$\begin{array}{lll}\text { rary Educational } & \text { Psychology, }\end{array}$ https://doi.org/10.1016/j.cedpsych.2010.11.002

Mann, L., Nota, L., Soresi, S., Ferrari, L., \& Frydenberg, E. (2011). The relationship between coping strategies, decision-coping patterns, and self-efficacy in adolescence. In G. M. Reevy and E. Frydenberg (Eds.), Personality, stress, and coping (pp. 25-48). Charlotte, NC: Information Age Publishing.

Noftle, E., \& Robins, R. (2007). Personality predictors of academic outcomes: Big five correlates of GPA and SAT scores. Journal of Personality and Social Psychology, 93(1), 116-130. https://doi.org/10.1037/0022-3514.93.1.116

Pabiton, C. P. (2004). Concerns, issues and coping strategies of international students in selected private universities in the Philippines. Philippines Journal of Counseling Centers, 6, 22-31.

Pabiton, C. P. (2007). Problems and coping strategies of university students: Implication for counseling centres. Philippine Journal of Counseling Centers, 6, 78-95.

Reevy, G. M. (2011). Relationship of big five traits and coping mechanisms with college grade point average. In G. M. Reevy and E. Frydenberg (Eds.), Personality, stress, and coping (pp. 191-216). Charlotte, NC: Information Age Publishing.

Reijntjes, A., Stegge, H., \& Terwogt, M. M. (2006). Children's coping with peer rejection: The role of depressive symptoms, social competence, and gender. Infant and Child Development, 15(1), 89-107. https://doi.org/10.1002/icd.435

Rust, J., \& Golombok, S. (1989). Modern psychometrics: The science of psychological assessment. London: Routledge. 
Steinfeldt, J. A., \& Steinfeldt, M. C. (2012). Profile of masculine norms and help-seeking stigma in college football. Sport, Exercise, and Performance Psychology, 1(1), 58-71. https://doi.org/10.1037/a0024919

van Uden, J. M., Ritzen, H., \& Pieters, J. M. (2013). I think I can engage my students: Teachers' perceptions of student engagement and their beliefs about being a teacher. Teaching and Teacher Education, 32, 43-54. https://doi.org/10.1016/j.tate.2013.01.004

van Uden, J. M., Ritzen, H., \& Pieters, J. M. (2014). Engaging students: The role of teacher beliefs and interpersonal teacher behavior in fostering student engagement in vocational education. Teaching and Teacher Education, 37, 21-32. https://doi.org/10.1016/j.tate.2013.08.005 